OPEN ACCESS

Edited by: Herve Boutin,

University of Manchester, United Kingdom

Reviewed by:

Matthew J. Robson,

University of Cincinnati, United States

Enrique José Cobos,

University of Granada, Spain

*Correspondence:

Stephen T. Safrany

ssafrany@rcsi-mub.com

${ }^{\dagger}$ Present address:

Haider Abbas,

Oncology Department, University Hospital Birmingham NHS Foundation

Trust, Birmingham,

United Kingdom

Specialty section:

This article was submitted to Experimental Pharmacology and Drug Discovery,

a section of the journal Frontiers in Pharmacology

Received: 06 May 2019 Accepted: 02 March 2020 Published: 13 March 2020

Citation:

Abbas $H$, Borde $P$, Willars GB, Ferry DR and Safrany ST (2020) Hazards of Using Masking Protocols

When Performing Ligand Binding Assays: Lessons From the Sigma-1 and Sigma-2 Receptors.

Front. Pharmacol. 11:309. doi: 10.3389/fphar.2020.00309

\section{Hazards of Using Masking Protocols When Performing Ligand Binding Assays: Lessons From the Sigma-1 and Sigma-2 Receptors}

\author{
Haider Abbas ${ }^{1,2 \dagger}$, Preeti Borde ${ }^{3}$, Gary B. Willars ${ }^{4}$, David R. Ferry ${ }^{5}$ \\ and Stephen T. Safrany ${ }^{3 *}$ \\ ${ }^{1}$ School of Pharmacy, University of Wolverhampton, Wolverhampton, United Kingdom, ${ }^{2}$ Oncology Department, New Cross \\ Hospital, Wolverhampton, United Kingdom, ${ }^{3}$ School of Medicine, RCSI-Bahrain, Adliya, Bahrain, ${ }^{4}$ Department of Molecular \\ and Cell Biology, University of Leicester, Leicester, United Kingdom, 5 Gastrointestinal Oncology Strategy, Eli Lilly, \\ Indianapolis, IN, United States
}

Sigma-1 and sigma-2 receptors are emerging therapeutic targets. Although the molecular identity of the sigma-2 receptor has recently been determined, receptor quantitation has used, and continues to use, the sigma-1 selective agents (+) pentazocine or dextrallorphan to mask the sigma-1 receptor in radioligand binding assays. Here, we have assessed the suitability of currently established saturation and competition binding isotherm assays that are used to quantify parameters of the sigma-2 receptor. We show that whilst the sigma-1 receptor mask (+) pentazocine has low affinity for the sigma-2 receptor $\left(K_{i} 406 \mathrm{nM}\right)$, it can effectively compete at this site with $\left[{ }^{3} \mathrm{H}\right]$ di-O-tolyl guanidine (DTG) at the concentrations frequently used to mask the sigma-1 receptor (100 nM and $1 \mu \mathrm{M}$ ). This competition influences the apparent affinity of DTG and other ligands tested in this system. A more troublesome issue is that DTG can displace (+) pentazocine from the sigma-1 receptor, rendering it partly unmasked. Indeed, commonly used concentrations of $(+)$ pentazocine, $100 \mathrm{nM}$ and $1 \mu \mathrm{M}$, allowed 37 and $11 \%$ respectively of sigma-1 receptors to be bound by DTG (300 nM), which could result in an overestimation of sigma-2 receptor numbers in assays where sigma-1 receptors are also present. Similarly, modelled data for $1 \mu \mathrm{M}$ dextrallorphan show that only $71-86 \%$ of sigma-1 receptors would be masked in the presence of 300 nM DTG. Therefore, the use of dextrallorphan as a masking agent would also lead to the overestimation of sigma-2 receptors in systems where sigma-1 receptors are present. These data highlight the dangers of using masking agents in radioligand binding studies and we strongly recommend that currently used masking protocols are not used in the study of sigma-2 receptors. In order to overcome these problems, we recommend the use of a cell line apparently devoid of sigma-1 receptors [e.g., MCF7 (ATCC HTB-22)] in the absence of any masking agent when determining the affinity of agents for the sigma-2 receptor. In addition, assessing the relative levels of sigma-1 and sigma-2 receptors can be achieved using $\left[{ }^{3 H}\right]$ DTG saturation binding followed by two-site analysis of $(+)$ pentazocine competition binding with $\left[{ }^{3 H}\right]$ DTG.

Keywords: dextrallorphan, di-O-tolyl guanidine, equilibrium binding, masking, (+) pentazocine, sigma-1 sigma-2, TMEM97 


\section{INTRODUCTION}

Sigma receptors were initially described as novel opioid receptors (Martin et al., 1976) but were later found to be a distinct class of receptors consisting of two subtypes: sigma- 1 and sigma-2. The sigma-1 receptor has been identified and cloned for some time (Hanner et al., 1996; Kekuda et al., 1996; Mei and Pasternak, 2001; Abate et al., 2010), with the crystal structure of the trimer being recently reported (Schmidt et al., 2016). The molecular identity of the sigma-2 binding site has only very recently been determined as TMEM97, an endoplasmic reticulum-resident transmembrane protein that regulates the sterol transporter NPC1 (Alon et al., 2017). It has been reported that both subtypes of the sigma receptor, but in particular sigma-2, are overexpressed in rapidly dividing normal cells and in tumour cell lines derived from various tissues (Vilner et al., 1995) highlighting a role in cell growth and proliferation with a potential link to cancer.

Sigma-1 receptors have been well-studied and several functions have been described including: modulation and synthesis of dopamine and acetylcholine (Booth and Baldessarini, 1991; Patrick et al., 1993); modulation of Nmethyl-D-aspartate (NMDA)-stimulated neurotransmitter release (Gonzalez-Alvear and Werling, 1995; Monnet et al., 1996); modulation of opioid analgesia (King et al., 1997); and neuroprotective and anti-amnesic activity (Maurice and Lockhart, 1997; Brimson et al., 2018). Sigma-1 receptor antagonists show promise in the treatment (Spruce et al., 2004) and diagnosis (van Waarde et al., 2015) of several cancers. Sigma-2 receptors are mainly involved in the regulation of cell proliferation and viability, with agonists driving changes in cell morphology and a reduction in cell division, leading ultimately to apoptosis (Bowen, 2000).

The current focus on the sigma-2 receptor is underpinned by the observation that its presence not only correlates with the proliferation of tumours but also that it plays an important role in cell survival. In vitro studies have shown that sigma-2 ligands can induce apoptosis and hence inhibit tumour growth. As such, it has been proposed that the sigma- 2 receptor could be used as both a diagnostic and therapeutic target (van Waarde et al., 2015). Indeed, trials are underway in these areas to determine the potential of the sigma- 2 receptor and its ligands in oncology. For example, early trials using radiolabelled sigma-2 ligands in PET imaging have shown success in imaging certain tumours. Furthermore, in vitro studies using pancreatic and ovarian cancer cell lines have shown significant increases in the pharmacological effects of chemotherapeutics when used in combination with sigma-2 ligands. Sigma-2 ligands conjugated with anti-cancer drugs are also under development to ensure targeted drug delivery in order to minimise the toxicities associated with chemotherapy (Zeng et al., 2017).

Sigma-1 receptors are usually quantified by radioligand binding assays using the selective ligand $(+)$ pentazocine that binds to the sigma-1 receptor with relatively high affinity. Binding of $(+)$ pentazocine to other proteins appears poor, leading to rapid dissociation from low-affinity sites and little contribution of background or non-specific binding to overall binding. Although described as an agonist, (+) pentazocine binds with a Hill slope of unity which is not affected by the inclusion of GTP or suramin. In contrast, antagonists bind with low Hill slopes. The addition of GTP or suramin causes loss of the highaffinity state of the sigma-1 receptor for the antagonist and leads to a Hill slope of unity being achieved (Brimson et al., 2011).

Problems arise, however, when radioligand binding assays are performed to study the sigma- 2 receptor. In this article, we show that this can overestimate the number of sigma-2 receptors present in a system where sigma-1 receptors are also present. This may also explain why sigma-2 receptors are described as ubiquitous (Stracina and Novakova, 2018).

The standard protocol used for identifying and quantifying the sigma- 2 receptor relies on the radioligand $\left[{ }^{3} \mathrm{H}\right]$ di-O-tolyl guanidine (DTG). DTG is a pan-sigma ligand, binding both receptors with equal affinity. As most binding assays have been performed in tissues or cell lines containing sigma-1 receptors, it has become standard to determine sigma-2 binding in the presence of either $(+)$ pentazocine or dextrallorphan to mask sigma-1 binding sites (Vilner et al., 1995; Chu et al., 2015; Chu and Ruoho, 2015). However, this protocol, whilst fully integrated into the sigma receptor researcher's toolkit, is seriously flawed. Here, we explain the reasons and consequences of relying on a masking protocol and offer alternatives.

\section{MATERIALS AND METHODS}

\section{General Materials}

Tissue culture media, antibiotics, trypsin, and serum were purchased from Invitrogen (Paisley, UK) or Sigma-Aldrich (Ireland). $\left[{ }^{3} \mathrm{H}\right](+)$ pentazocine $((1 S, 9 S, 13 S)$-1,13-dimethyl-10(3-methylbut-2-en-1-yl)-10-azatricyclotrideca-2,4,6-trien-4-ol) and $\left[5-{ }^{3} \mathrm{H}(\mathrm{N})\right]-1,3$-di-O-tolylguanidine (DTG) were purchased from PerkinElmer (Beaconsfield, UK). Other reagents were purchased from Sigma-Aldrich (Poole, UK). Before use, drugs were dissolved in an appropriate vehicle and diluted in assay buffer. The $\mathrm{pH}$ of each solution was adjusted to 7.4.

\section{Tissue Culture and Membrane Preparation} MDA-MB-468 (ATCC HTB-132) and MCF7 (ATCC HTB-22) breast cancer cell lines were obtained from LGC Promotech, UK. MDA-MB-468 cells were maintained in DMEM, high glucose (41965-062) supplemented with $10 \%$ foetal calf serum. MCF7 cells were maintained in MEM (M2279) supplemented with $2 \mathrm{mM} \mathrm{L-}$ glutamine and $10 \%$ foetal calf serum. Cells were cultured at $37^{\circ} \mathrm{C}$ in a humidified incubator with $5 \% \mathrm{CO}_{2}$. To prepare membranes for binding studies, cells were suspended in sigma binding buffer [SBB: 50 mM Tris-HCl; pH 8.0, (Vilner et al., 1995)], sonicated (1 $\min )$, and then centrifuged $\left(22,000 \mathrm{~g}, 20 \mathrm{~min}, 4^{\circ} \mathrm{C}\right)$. The supernatant was discarded and the pellet suspended in SBB.

\section{Saturation Binding}

Sigma-1 Receptor Binding

Assays (total volume $100 \mu \mathrm{l}$ ) were performed using 0-300 nM $\left[{ }^{3} \mathrm{H}\right](+)$ pentazocine at room temperature for $2 \mathrm{~h}$ in SBB as previously described (Vilner et al., 1995). Non-specific binding was determined using $1 \mathrm{mM}$ reduced haloperidol 
(Schetz et al., 2007). The concentration of reduced haloperidol to determine non-specific binding was higher than in previous studies, as assays described below used higher concentrations of radioligand than used in standard radioligand binding assays. Assays were terminated by addition of ice-cold tris-buffered saline (TBS: $154 \mathrm{mM} \mathrm{NaCl}, 10 \mathrm{mM}$ Tris, $\mathrm{pH}$ 7.4) and filtration through glass fibre filters (GF/B, Sigma-Aldrich, Poole, UK) using a cell harvester. Tubes and filter discs were washed $(2 \times 3 \mathrm{ml})$ with icecold TBS, and the filter discs dried under vacuum. Scintillation counting was carried out in ProSafe FC+ cocktail (Meridian Biotechnologies Ltd, Tadworth, UK) after overnight incubation.

\section{Sigma-2 Receptor Binding}

Assays (total volume $100 \mu \mathrm{l}$ ) were performed at room temperature for $4 \mathrm{~h}$ with 1-300 $\mathrm{nM}\left[{ }^{3} \mathrm{H}\right]$ DTG in SBB. Non-specific binding was determined using $1 \mathrm{mM}$ reduced haloperidol. To investigate the effects of $(+)$ pentazocine, $\left[{ }^{3} \mathrm{H}\right]$ DTG saturation curves were performed in the absence or presence of $(+)$ pentazocine $[100 \mathrm{nM}$ (Chu and Ruoho, 2015) or $1 \mu \mathrm{M}$ (Shiba et al., 2005; Xu et al., 2005)]. Assays were terminated by addition of ice-cold TBS and filtration through glass fibre filters (GF/C, Sigma-Aldrich, Poole, UK) using a cell harvester. Tubes and filter discs were washed with ice-cold TBS ( $2 \times 3 \mathrm{ml})$ and the filter discs dried under vacuum. Scintillation counting was carried out in ProSafe FC+ cocktail after overnight incubation.

\section{Competition Binding Assays}

Competition binding assays (total volume $100 \mu \mathrm{l}$ ) were performed using a final assay concentration of $50 \mathrm{nM}, 100 \mathrm{nM}$, or $1 \mu \mathrm{M}\left[{ }^{3} \mathrm{H}\right](+)$ pentazocine with increasing concentrations of DTG (10 nM-1 mM). Alternatively, $10-30 \mathrm{nM}\left[{ }^{3} \mathrm{H}\right]$ DTG was employed in the presence of increasing concentrations of $(+)$ pentazocine $(10 \mathrm{nM}-1 \mathrm{mM})$. The assay was then allowed to equilibrate at room temperature for $4 \mathrm{~h}$. After equilibration, the membranes were harvested by rapid filtration through GF/B $\left(\left[{ }^{3} \mathrm{H}\right](+)\right.$ pentazocine) or GF/C $\left(\left[{ }^{3} \mathrm{H}\right]\right.$ DTG) glass fibre filters. Tubes and filter discs were washed with ice-cold TBS $(2 \times 3 \mathrm{ml})$, and the filter discs dried under vacuum. Non-specific binding was determined using $1 \mathrm{mM}$ reduced haloperidol. Under these conditions less than $10 \%$ of either the $\left[{ }^{3} \mathrm{H}\right](+)$ pentazocine or $\left[{ }^{3} \mathrm{H}\right]$ DTG was bound.

All data were calculated and presented using GraphPad Prism v7.02.

\section{Modelling of Dextrallorphan Binding}

Whilst (+) pentazocine is the masking drug used by most researchers, several publications have used dextrallorphan as an alternative. We were unable to obtain dextrallorphan for these studies and have therefore modelled binding experiments using published data. Methods for and results from the modelling can be found in Supplementary Material.

\section{RESULTS}

Saturation binding of $\left[{ }^{3} \mathrm{H}\right](+)$ pentazocine to membranes prepared from MCF7 and MDA-MB-468 cells was performed.
MDA-MB-468 cell membranes showed binding with $\mathrm{K}_{\mathrm{d}} 22 \mathrm{nM}$ $\left(\mathrm{pK}_{\mathrm{d}}=7.65 \pm 0.13\right)$ and $\mathrm{B}_{\max }$ of $1,730 \pm 330 \mathrm{fmol} / \mathrm{mg}$ protein (Figure 1). There was no specific binding of $\left[{ }^{3} \mathrm{H}\right](+)$ pentazocine to MCF7 cell membranes detected (data not shown). Saturation binding curves were also performed using the pan-sigma ligand $\left[{ }^{3} \mathrm{H}\right]$ DTG, which bound to MCF7 cells with $\mathrm{K}_{\mathrm{d}} 12 \mathrm{nM}\left(\mathrm{pK}_{\mathrm{d}}=\right.$ $7.92 \pm 0.03, \mathrm{n}=3$ ) and MDA-MD-468 cell membranes with $\mathrm{K}_{\mathrm{d}}$ $13 \mathrm{nM}\left(\mathrm{pK}_{\mathrm{d}} 7.88 \pm 0.01, \mathrm{n}=3\right)$. The $\mathrm{B}_{\max }$ values were $2,050 \pm 100$ and $850 \pm 200 \mathrm{fmol} / \mathrm{mg}$ protein for MCF7 and MDA-MB-468 cells respectively (Figure 2 ).

Figure 3 shows that $(+)$ pentazocine readily competed with the pan-sigma ligand $\left[{ }^{3} \mathrm{H}\right]$ DTG for the sigma-2 receptor. Our assays were performed using membranes prepared from MCF7 cells, which show no specific binding of $\left[{ }^{3} \mathrm{H}\right](+)$ pentazocine in radioligand binding assays [Figure $\mathbf{1}$ and (Vilner et al., 1995)], and so express very few, if any, sigma-1 receptors. Competition assays were performed using low concentrations (10-30 nM) of $\left[{ }^{3} \mathrm{H}\right]$ DTG. An $\mathrm{IC}_{50}$ of $620 \mathrm{nM}$ was determined, resulting in a $\mathrm{K}_{\mathrm{i}}$ of $406 \mathrm{nM}\left(\mathrm{pK}_{\mathrm{i}}=6.39 \pm 0.07, \mathrm{n}=4\right)$ calculated using the ChengPrusoff correction. These results show that whilst the interaction between sigma-2 receptors and $(+)$ pentazocine cannot be shown directly using $\left[{ }^{3} \mathrm{H}\right](+)$ pentazocine, there is a clear, measurable interaction.

We next sought to determine whether the inclusion of $(+)$ pentazocine would affect the saturation curve of $\left[{ }^{3} \mathrm{H}\right]$ DTG, performing the assay in accordance with frequently used protocols (Chu and Ruoho, 2015). Assays were performed using $\left[{ }^{3} \mathrm{H}\right]$ DTG $(1-300 \mathrm{nM})$ in the absence and presence of (+) pentazocine $(100 \mathrm{nM}$ or $1 \mu \mathrm{M})$ with membranes prepared from MCF7 cells, which, as highlighted above, show no specific binding of $\left[{ }^{3} \mathrm{H}\right](+)$ pentazocine at the concentrations used in radioligand binding assays. A rectangular hyperbolic curve was obtained in all three conditions (Figure 4). Using GraphPad Prism to plot the saturation curves allowed comparisons of $\mathrm{K}_{\mathrm{d}}$,

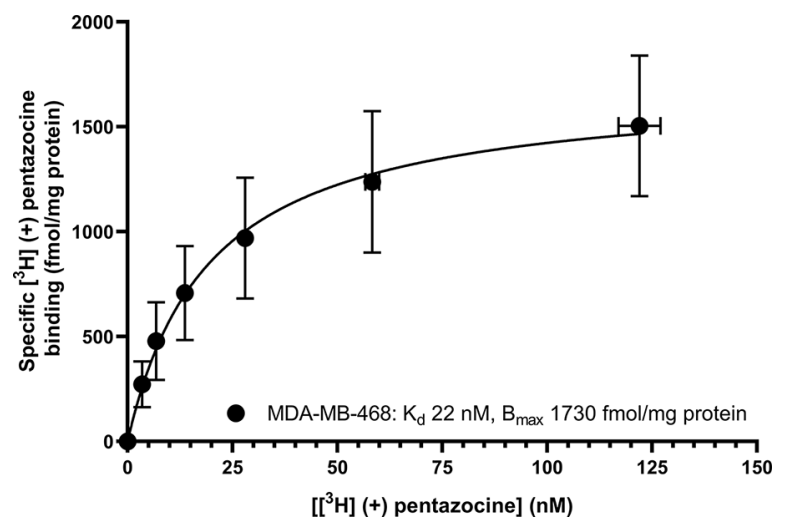

FIGURE 1 | Saturation binding curve for $\left[{ }^{3} \mathrm{H}\right](+)$ pentazocine to membranes prepared from MDA-MB-468 cells. Non-specific binding was determined in the presence of $1 \mathrm{mM}$ reduced haloperidol. Data represent mean $\pm \mathrm{SEM}$ for both binding and radioligand concentration from three independent experiments. No specific binding was observed using $\left[{ }^{3} \mathrm{H}\right](+)$ pentazocine and membranes prepared from MCF7 cells. 


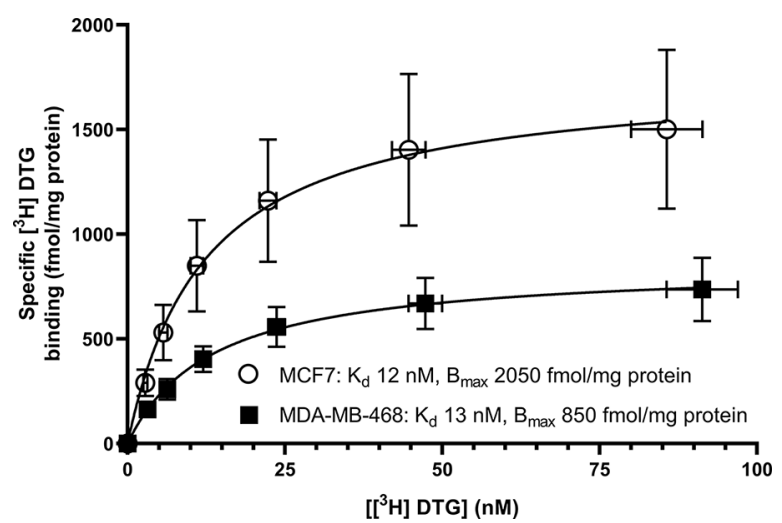

FIGURE 2 | Saturation binding curve for the pan-sigma ligand, [3H] DTG, to membranes prepared from MDA-MB-468 cells (filled squares) and MCF7 cells (open circles). Non-specific binding was determined in the presence of $1 \mathrm{mM}$ reduced haloperidol. Data represent mean \pm SEM for both binding and radioligand concentration from three independent experiments.

apparent $\mathrm{K}_{\mathrm{d}}$ and $\mathrm{B}_{\max }$ values. We have deliberately not presented results in the form of Scatchard plots, as such linear transformations are not considered suitable for statistical analysis or determination of $\mathrm{K}_{\mathrm{d}}$ or $\mathrm{B}_{\max }$ values (Rodbard et al., 1980; GraphPad, 2020). These experiments were performed using a different batch of $\left[{ }^{3} \mathrm{H}\right]$ DTG to that used in the saturation binding experiments described above, and a modest difference in $\mathrm{K}_{\mathrm{d}}$ for DTG was observed between this experiment $\left(37 \mathrm{nM}, \mathrm{pK}_{\mathrm{d}}=7.43 \pm 0.10\right.$, mean \pm SEM, $\left.\mathrm{n}=11\right)$ and the saturation analysis shown in Figure $2(12 \mathrm{nM})$. The highest concentration of DTG used ( $300 \mathrm{nM}$ ) bound $88 \%$ of the available receptors based on the rectangular hyperbolic fit observed in Figure 2. As expected, the inclusion of $100 \mathrm{nM}(+)$ pentazocine

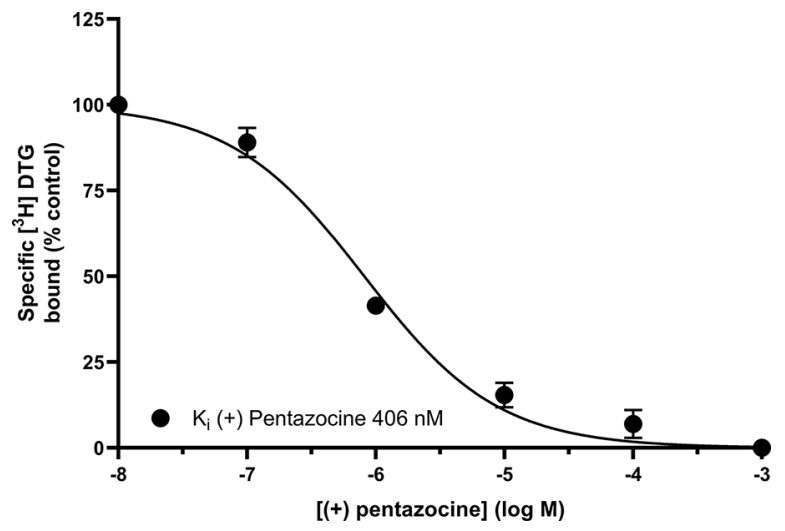

FIGURE 3 | Displacement of [3H] DTG from sigma-2 receptors by $(+)$ pentazocine. Although no binding was detected using $\left[{ }^{3} \mathrm{H}\right](+)$ pentazocine, the competition binding curve shows displacement of [ $\left.{ }^{3} \mathrm{H}\right]$ DTG from sigma-2 receptors in membranes prepared from MCF7 cells by increasing (+) pentazocine concentrations. Non-specific binding was determined in the presence of $1 \mathrm{mM}$ reduced haloperidol. Data represent mean $\pm \mathrm{SEM}$ from four independent experiments.

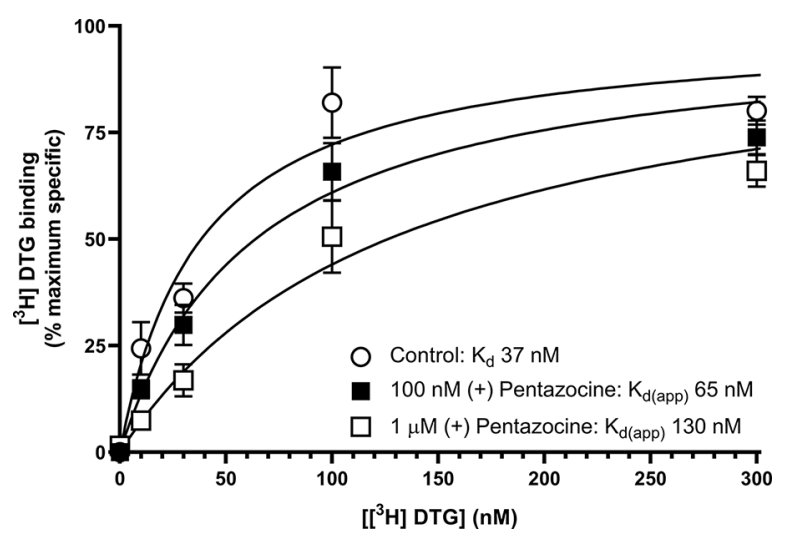

FIGURE 4 | Effect of $(+)$ pentazocine on the saturation binding of [ $\left.{ }^{3} \mathrm{H}\right]$ DTG to sigma-2 receptors in MCF7 cell membranes. Saturation binding curves for [ $\left.{ }^{3} \mathrm{H}\right]$ DTG to membranes prepared from MCF7 cells were performed in the absence (open circles) or presence of $(+)$ pentazocine (100 nM, filled squares; $1 \mu \mathrm{M}$, open squares). Non-specific binding was determined in the presence of $1 \mathrm{mM}$ reduced haloperidol. Data represent mean \pm SEM from 11 independent experiments. $\mathrm{K}_{\mathrm{d}(\mathrm{app})}=$ apparent $\mathrm{K}_{\mathrm{d}}$ in the presence of competitor.

did not affect $\mathrm{B}_{\max }$ calculations. The apparent $\mathrm{K}_{\mathrm{d}}$ was moderately increased to $65 \mathrm{nM}\left(\mathrm{pK}_{\mathrm{d}}=7.19 \pm 0.09\right.$, mean \pm SEM, $\left.\mathrm{n}=11\right)$ with DTG (300 $\mathrm{nM}$ ) binding $82 \%$ of the available receptors. Inclusion of the higher concentration of $(+)$ pentazocine $(1 \mu \mathrm{M})$ again did not affect the calculated $B_{\max }$. However, the apparent $K_{d}$ was shifted even higher: $130 \mathrm{nM}\left(\mathrm{pK}_{\mathrm{d}}=6.89 \pm 0.09\right.$, mean \pm SEM, $\mathrm{n}=$ 11 ) and DTG $(300 \mathrm{nM})$ binding $71 \%$ of the receptors available. These data show that the frequently used protocol for establishing $K_{d}$ and $B_{\max }$ for sigma-2 receptors would give a raised $K_{d}$ value for DTG, whilst recognising all sigma-2 receptors in the system.

We also investigated whether $\left[{ }^{3} \mathrm{H}\right]$ DTG could compete with the masking agent $(+)$ pentazocine and bind to sigma-1 receptors. In order to observe loss of $(+)$ pentazocine binding to these sites, experiments were performed in membranes prepared from MDA-MB-468 cells. Incubations of $\left[{ }^{3} \mathrm{H}\right](+)$ pentazocine $(100 \mathrm{nM}$ and $1 \mu \mathrm{M})$ were performed with the inclusion of increasing concentrations of DTG. Radioligand binding assays are rarely performed with the concentrations of radioligand used here. Preparations of $\left[{ }^{3} \mathrm{H}\right](+)$ pentazocine were mixed with unlabelled $(+)$ pentazocine to obtain stocks suitable for these binding studies. The binding of $100 \mathrm{nM}\left[{ }^{3} \mathrm{H}\right](+)$ pentazocine was reduced by increasing concentrations of DTG with an $\mathrm{IC}_{50}$ of $760 \mathrm{nM}\left(\mathrm{pIC}_{50}=6.1 \pm 0.2\right.$, mean $\left.\pm \mathrm{SEM}, \mathrm{n}=8\right)$. When considering data using $1 \mu \mathrm{M}\left[{ }^{3} \mathrm{H}\right](+)$ pentazocine, DTG was, as expected, less effective, with an $\mathrm{IC}_{50}$ of $2.2 \mu \mathrm{M}\left(\mathrm{pIC}_{50}=\right.$ $5.7 \pm 0.4$, mean \pm SEM, $\mathrm{n}=6$ ) (Figure 5). Using the ChengPrusoff correction, $\mathrm{K}_{\mathrm{i}}$ values of 137 and $47 \mathrm{nM}$ for DTG can be calculated at $100 \mathrm{nM}$ and $1 \mu \mathrm{M}\left[{ }^{3} \mathrm{H}\right](+)$ pentazocine respectively. Interpolation of the curves allows calculation of the amount of $\left[{ }^{3} \mathrm{H}\right](+)$ pentazocine displaced from the sigma- 1 sites at different concentrations of DTG (Table 1). Data show that $37 \%$ of $100 \mathrm{nM}$ $\left[{ }^{3} \mathrm{H}\right](+)$ pentazocine and $17 \%$ of $1 \mu \mathrm{M}\left[{ }^{3} \mathrm{H}\right](+)$ pentazocine was 


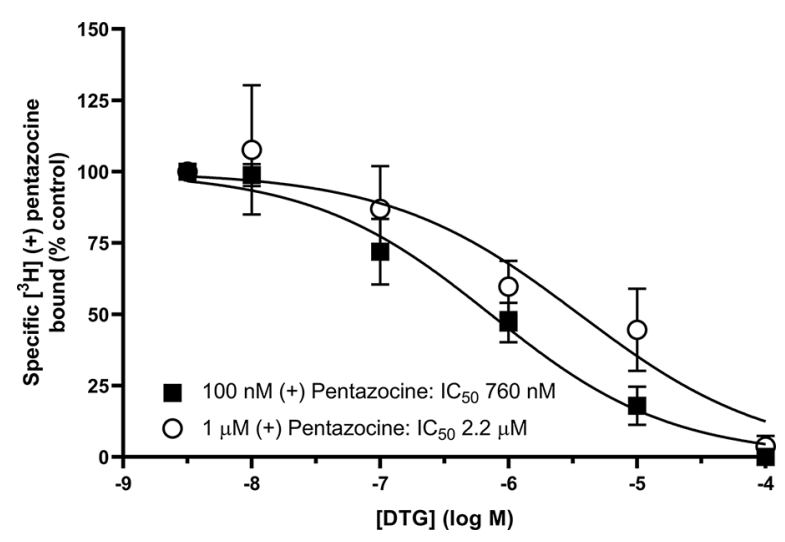

FIGURE 5 | Displacement of $\left[{ }^{3} \mathrm{H}\right](+)$ pentazocine from sigma-1 receptors by DTG. Competition binding curve showing the displacement of either $100 \mathrm{nM}$ (filled squares) or $1 \mu \mathrm{M}$ (open circles) $\left[{ }^{3} \mathrm{H}\right](+)$ pentazocine from sigma-1 receptors in membranes prepared from MDA-MB-468 cells by increasing DTG concentrations. Non-specific binding was determined in the presence of $1 \mathrm{mM}$ reduced haloperidol. Data represent mean \pm SEM from $8\left(100 \mathrm{nM}\left[{ }^{3} \mathrm{H}\right]\right.$ (+) pentazocine) or $6\left(1 \mu \mathrm{M}\left[{ }^{3} \mathrm{H}\right](+)\right.$ pentazocine) independent experiments.

displaced by $300 \mathrm{nM}$ DTG. These data show that under conditions frequently used, up to $37 \%$ of sigma-1 receptors present would contribute to the DTG signal and inflate the $\mathrm{B}_{\max }$ value. In extreme circumstances, this could account for all the binding observed.

We offer one possible remedy to the current problem of assessing levels of sigma- 1 and sigma- 2 receptors in cells and tissues in the absence of commercially available sigma-2 receptor-selective radioligands: Figure $\mathbf{6}$ shows competition binding between a fixed concentration of $\left[{ }^{3} \mathrm{H}\right]$ DTG and a range of concentrations of unlabelled $(+)$ pentazocine in MDA-MB-468 and MCF7 cell membranes. A monophasic competition curve is observed in MCF7 cell membranes. This indicates a single, low affinity site $\left(\mathrm{IC}_{50} 3.3 \mu \mathrm{M}\right)$ is present. In contrast, MDA-MB-468 cells show the existence of sites with high- and low-affinity for (+) pentazocine. Two-site analysis (GraphPad Prism) identifies that $36 \%$ of these sites had high affinity $\left(\mathrm{IC}_{50} 21 \mathrm{nM}\right)$, indicating these are sigma-1 receptors, with the remaining $64 \%$ with a low affinity $\left(\mathrm{IC}_{50} 1.3 \mu \mathrm{M}\right)$, representing sigma-2 receptors.

We note that not all groups use $(+)$ pentazocine to mask sigma-1 receptors. Indeed, several publications have used

TABLE 1 | Displacement of $\left[{ }^{3} \mathrm{H}\right](+)$ pentazocine from sigma-1 receptors by increasing concentrations of DTG.

\begin{tabular}{lccccc}
\hline$\left[{ }^{3} \mathbf{H}\right](+)$ pentazocine] & $\begin{array}{c}\text { [DTG] } \\
\mathbf{3} \mathbf{~} \mathbf{M}\end{array}$ & $\begin{array}{c}\text { [DTG] } \\
\mathbf{1 0} \mathbf{~ n M}\end{array}$ & $\begin{array}{c}\text { [DTG] } \\
\mathbf{3 0} \mathbf{~ n M}\end{array}$ & $\begin{array}{c}\text { [DTG] } \\
\mathbf{1 0 0} \mathbf{~} \mathbf{M}\end{array}$ & $\begin{array}{c}\text { [DTG] } \\
\mathbf{3 0 0} \mathbf{~ n M}\end{array}$ \\
\hline $100 \mathrm{nM}$ & $2.5 \pm 0.9$ & $4.7 \pm 1.6$ & $8.6 \pm 2.6$ & $26.3 \pm 9.9$ & $37 \pm 11$ \\
$1 \mathrm{HM}$ & $2.9 \pm 2.5$ & $4.8 \pm 3.9$ & $7.6 \pm 5.9$ & $11.6 \pm 8.2$ & $17 \pm 11$ \\
\hline
\end{tabular}

Data represent $[3 \mathrm{H}](+)$ pentazocine displaced by increasing concentrations of DTG (as \% of binding in the absence of DTG). Data (mean \pm SEM) are interpolated from individual competition curves, $n=8$ (100 nM (+) pentazocine) and $n=6$ (1 $\mu \mathrm{M}(+)$ pentazocine). Values are derived using the data presented in Figure 5

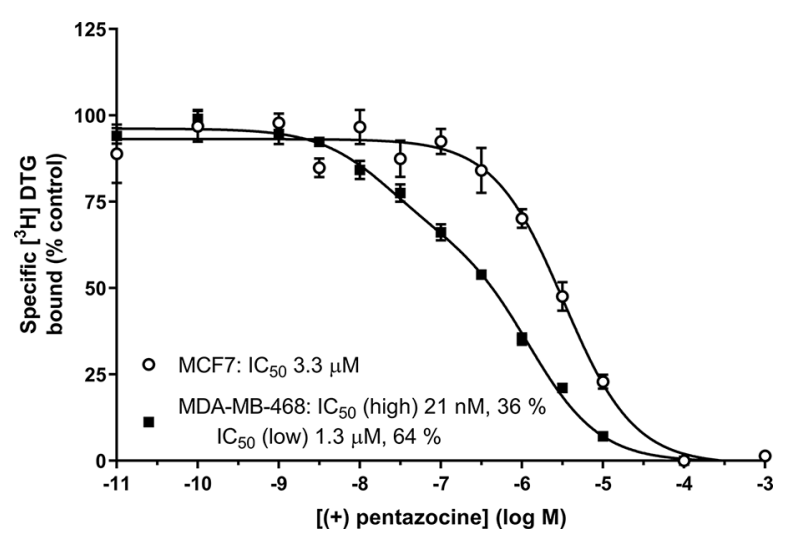

FIGURE 6 | Displacement of [ $\left.{ }^{3} \mathrm{H}\right]$ DTG from sigma receptors by $(+)$ pentazocine. Competition binding curve showing the displacement of $\left[{ }^{3} \mathrm{H}\right]$ DTG from membranes prepared from MDA-MB-468 cells (filled squares) and MCF7 cells (open circles) by increasing $(+)$ pentazocine concentrations. Nonspecific binding was determined in the presence of $1 \mathrm{mM}$ reduced haloperidol. Data represent mean \pm SEM from 5 (MDA-MB-468) and 4 (MCF7) independent experiments. Curve fitting was achieved comparing a one- and two-site fit (GraphPad Prism).

dextrallorphan. Unfortunately, we have not been able to obtain this ligand but have used modelling to determine whether this may provide a better sigma-1 receptor mask than (+) pentazocine. Results presented in Supplementary Material suggest that $1 \mu \mathrm{M}$ dextrallorphan would bind 2.2$6.3 \%$ of the sigma-2 receptors. The addition of $300 \mathrm{nM}$ DTG would displace $88 \%$ of this binding. However, DTG would also displace dextrallorphan from the sigma-1 receptor, rendering only $71.5-86.1 \%$ of sigma-1 receptors masked (see Supplementary Material).

From the above data, it is clear that none of the masking protocols widely accepted should be used. Addition of DTG will compete with the binding of $(+)$ pentazocine and dextrallorphan to both sigma- 1 and sigma- 2 sites.

\section{DISCUSSION AND CONCLUSIONS}

The results presented here are in keeping with previously published data on all of the agents used. Our affinity of $22 \mathrm{nM}$ for $(+)$ pentazocine at the sigma-1 receptor is both internally and externally consistent. We have previously shown affinities of $7.7 \mathrm{nM}$ (Spruce et al., 2004) and $17 \mathrm{nM}$ (Brimson et al., 2011) (obtained from MDA-MB-468 membranes and permeabilised cells, respectively). A selection of data from other studies with a variety of tissues and conditions gives overlapping results: guinea pig liver microsomes (0.8 nM) (Hanner et al., 1996); mouse lung membranes (1.4 nM) (Lever et al., 2015); guinea pig brain membranes (1.6 nM obtained by means of homologous competition) (Xu et al., 2015); mouse brain homogenates (5.1 nM) (Langa et al., 2003); bovine adrenal medullar membranes (18 nM) (Paul et al., 1993); and rat cerebral membranes (19.9 nM) (Shiba et al., 2005). It is recognised that 
differences in the sigma-1 receptor sequences from different species may contribute to some variation in affinity. Only one of the above studies (Hanner et al., 1996) used recombinant protein with a known sequence. In the present study, $\left[{ }^{3} \mathrm{H}\right] \mathrm{DTG}$ gave a $B_{\max }$ of 2,050 $\pm 100 \mathrm{fmol} / \mathrm{mg}$ protein of sigma receptors in MCF7 cells. In the absence of any measureable specific $\left[{ }^{3} \mathrm{H}\right](+)$ pentazocine binding, we consider these to be sigma-2 receptors. This is in agreement with previously published data of 2,071 $\mathrm{fmol} / \mathrm{mg}$ protein (Vilner et al., 1995) in these cells. It is, of course, possible that low levels of sigma-1 receptors are expressed in these MCF7 cells obtained from ATCC. Indeed, Western blotting and immunocytochemical analysis of MCF7 cells obtained from ECACC (Radif et al., 2018) demonstrated the presence of sigma1 receptors but to our knowledge, no direct comparison of MCF7 cells from these different sources has been made.

The inclusion of $(+)$ pentazocine in binding assays using MCF7 cells caused a rightward shift in the $\mathrm{K}_{d}$ of $\left[{ }^{3} \mathrm{H}\right]$ DTG binding, but had no effect on $\mathrm{B}_{\max }$ calculations. This is unsurprising as $(+)$ pentazocine and $\left[{ }^{3} \mathrm{H}\right]$ DTG are competing at the sigma-2 receptors. However, the percentage of sigma-2 receptors bound by DTG at $300 \mathrm{nM}$ DTG falls from $88 \%$ (no (+) pentazocine) to $71 \%$ in the presence of $1 \mu \mathrm{M}(+)$ pentazocine, based on interpolation of values shown in Figure 4. Our $\mathrm{K}_{\mathrm{d}}$ values of DTG for the sigma-2 receptor, $12-37 \mathrm{nM}$, are difficult to compare with previous data, as most reported data have been made in the presence of $100 \mathrm{nM}-1 \mu \mathrm{M}(+)$ pentazocine or $1 \mu \mathrm{M}$ dextrallorphan. Examples include: $22.3 \mathrm{nM}$ (Shiba et al., 2005); $25 \mathrm{nM}$ (Vilner et al., 1995); $30.7 \mathrm{nM}$ (Xu et al., 2005); $39.9 \mathrm{nM}$ (Lever et al., 2006); and 74.8-91.1 nM (Chu et al., 2015). In this respect, our data are in keeping with, and highly comparable to, previous data. As such, our conclusions should be considered relevant to all using these reagents.

The affinity of $(+)$ pentazocine for the sigma-2 receptor has been reported in a number of published studies. However, data in the present study, along with consideration of the methods used in many of the previous studies suggest that a re-evaluation might be appropriate. For example: a $\mathrm{K}_{\mathrm{d}}$ of $56 \mathrm{nM}$ was reported for $(+)$ pentazocine at the sigma-2 receptor in guinea pig brain homogenates ('in the presence of an excess of non-radiolabelled (+) pentazocine for selective masking of sigma-1 receptors') (Sunnam et al., 2011); $327 \mathrm{nM}$ in rat liver homogenate (in the presence of $100 \mathrm{nM}(+)$ pentazocine to mask sigma-1 receptors) (Zampieri et al., 2009); $728 \mathrm{nM}$ in guinea pig brain membranes (in the presence of $200 \mathrm{nM}(+)$ pentazocine) (Lever et al., 2006); $1,440 \mathrm{nM}$ in rat brain homogenates (in the presence of $1 \mu \mathrm{M}(+)$ pentazocine) (Xu et al., 2005); and $2680 \mathrm{nM}$ in rat cerebral membranes (in the presence of $1 \mu \mathrm{M}(+)$ pentazocine) (Shiba et al., 2005). Values reported in the absence of a masking concentration of $(+)$ pentazocine include: $1.7-3.3 \mu \mathrm{M}$ (reported in C6 and NG115-08 cells in the absence of masking agent; these cells were reported as having a very low density of high-affinity (+) pentazocine binding sites) and 2.1-9.4 $\mu \mathrm{M}$ (in the presence of $1 \mu \mathrm{M}$ dextrallorphan) (Vilner et al., 1995). Thus, although the affinity of $(+)$ pentazocine has been widely reported, the effects of this relatively low-affinity binding have been underestimated.
Our experimental data show the apparent $\mathrm{K}_{\mathrm{d}}$ of $\left[{ }^{3} \mathrm{H}\right]$ DTG binding to the sigma-2 receptor increases with increasing (+) pentazocine concentration. Equally, the calculation of $\mathrm{K}_{\mathrm{i}}$ values for novel compounds acting at sigma-2 receptors would be complicated, as DTG, (+) pentazocine and the test compound will be competing at the same site. There may be additional complications if compounds also bind to the sigma-1 receptor with high affinity. If this results in substantial ligand depletion, estimates of affinity at the sigma-2 receptor would be compromised. We would suggest that ideally, determination of binding parameters for the sigma-2 receptor would be best performed using $\left[{ }^{3} \mathrm{H}\right]$ DTG and cell preparations devoid of sigma-1 receptors, thereby avoiding the need for a masking agent. This could include, for example, MCF7 cell membranes, although caution should be applied as we have found some of these to contain sigma-1 receptors (Spruce et al., 2004; Radif et al., 2018).

The consequences of the low affinity binding of (+) pentazocine to sigma-2 receptors are likely to be minimal when reporting $B_{\max }$ values for these receptors in membrane preparations. However, the ability of DTG to compete with $(+)$ pentazocine for sigma- 1 receptors is a major concern when $(+)$ pentazocine is being used as a mask for sigma- 1 receptors. To date, we are unaware of any cell or tissue reported as lacking sigma-2 receptors but we suggest that determination of sigma-2 sites should be revisited. Data presented here bring into question the previously accepted method of calculating sigma-2 receptor levels in cell lines using $\left[{ }^{3} \mathrm{H}\right]$ DTG in the presence of either $(+)$ pentazocine or dextrallorphan to mask sigma-1 receptors. Indeed, our data clearly highlight that the number of sigma-2 receptors will have been overestimated using such methodology, as it is likely that, if present, sigma-1 receptors will also have bound $\left[{ }^{3} \mathrm{H}\right]$ DTG.

In terms of any underlying biology, there is little rationale for comparisons between sigma- 1 and sigma- 2 receptors as, after all, they are very different proteins with very different roles. Despite this, a reliable protocol for determination of sigma-2 sites in the presence of sigma-1 receptors is required. Thus, we propose that alternative methodology is employed to quantitate sigma-2 receptor levels, specifically where masking agents are excluded. The use of $(+)$ pentazocine for the quantitation of sigma-1 receptors is greatly entrenched in our research methodologies. Unless a direct comparison of sigma-1 and sigma-2 receptor levels is required, an ideal way would be to use sigma- 2 receptor selective tools (Zeng et al., 2017). However, until these agents are commercially available, we suggest that an alternative would be to use $\left[{ }^{3} \mathrm{H}\right]$ DTG to obtain levels of total sigma binding sites (i.e., sigma-1 plus sigma-2 receptors) accompanied by competition binding with $(+)$ pentazocine or another agent selective for one particular receptor. Subsequent two-site analyses would then allow determination of the relative amounts of each target. Such methodology has been used previously: in a rarely cited paper (Kovacs and Larson, 1995) it was shown that $\left[{ }^{3} \mathrm{H}\right]$ DTG can be used to label all sigma sites. Using sigma-1-selective agents a biphasic competition curve was demonstrated, equivalent to 
sigma-1 and sigma-2 sites. Computer assisted data analysis (e.g. GraphPad Prism, as used here) is sufficiently developed to determine the presence of even a relatively small proportion of a second (affinity) binding site.

Although the methodology described above may provide an alternative strategy for determination of sigma-1 and sigma-2 receptors, this approach has generated inconsistencies. Kovacs and Larson (1995) showed that in spinal cord, $\left[{ }^{3} \mathrm{H}\right]$ DTG alone bound $150 \%$ of the sites labelled by $\left[{ }^{3} \mathrm{H}\right](+)$ pentazocine, suggesting there were twice as many sigma-1 receptors as sigma-2 receptors. However, when the competition experiments were performed, these suggested the reverse, as (+) pentazocine only displaced $30 \%$ of the $\left[{ }^{3} \mathrm{H}\right]$ DTG with high affinity (Kovacs and Larson, 1995). Similarly, $\left[{ }^{3} \mathrm{H}\right]$ DTG bound to fewer sites than $\left[{ }^{3} \mathrm{H}\right](+)$ pentazocine in several regions of the brain (Walker et al., 1990). Our results with MDA-MB-468 cells also show this discrepancy: Figure 1 shows that MDA-MB-468 cells had a $B_{\max }$ of $1730 \mathrm{fmol} /$ $\mathrm{mg}$ protein for $\left[{ }^{3} \mathrm{H}\right](+)$ pentazocine and only $850 \mathrm{fmol} / \mathrm{mg}$ protein for the pan-sigma ligand $\left[{ }^{3} \mathrm{H}\right]$ DTG. Figure 5 then shows that $36 \%$ of these $\left[{ }^{3} \mathrm{H}\right]$ DTG binding sites were sigma-1 receptors. Whether such discrepancies arise as a consequence of, for example, the given values of radioligand specific activity, breakdown of the radioligand, tritium exchange between the ligand, and other constituents (including water) or the presence of labelled precursor molecules (Lazareno and Birdsall, 2000) remains to be established. Until that point, this protocol would benefit from further consideration before it is widely accepted.

In addition to the issues described above, two recent publications highlight the possibility that $\left[{ }^{3} \mathrm{H}\right]$ DTG binds to something other than sigma-2 receptors. Thus, knock-out of the recently identified sigma-2 binding site, TMEM97, in HeLa cells showed residual binding sites for $\left[{ }^{3} \mathrm{H}\right]$ DTG (Riad et al., 2018; Zeng et al., 2019). These sites had an apparent $\mathrm{K}_{\mathrm{d}}$ for DTG of $300-$ $400 \mathrm{nM}$, with assays performed in the presence of $1 \mu \mathrm{M}(+)$ pentazocine (to mask the sigma-1 receptor). Utilising a derivation of the Michaelis-Menten equation for a competitive antagonist $\left(\mathrm{K}_{\mathrm{d}(\mathrm{app})}=\mathrm{K}_{\mathrm{d}}{ }^{*}\left(1+[\mathrm{I}] / \mathrm{K}_{\mathrm{i}}\right)\right.$, where $\mathrm{K}_{\mathrm{d}(\mathrm{app})}$ is the apparent $\mathrm{K}_{\mathrm{d}}$ of the radioligand in the presence of a competitor at fixed concentration) and the values given in this paper (DTG $\mathrm{K}_{\mathrm{d}}=12 \mathrm{nM}$, (+) pentazocine $\mathrm{K}_{\mathrm{i}}$ (sigma- 1 receptor) $=22 \mathrm{nM}$, [(+) pentazocine $]=$ $1 \mu \mathrm{M}$ ), the calculated $\mathrm{K}_{\mathrm{d}(\mathrm{app})}$ for DTG is $557 \mathrm{nM}$, which is well within experimental error for suggesting that this residual binding site may be the sigma- 1 receptor, despite the suggestion that this is unlikely (Riad et al., 2018). It is noteworthy that RHM-4, a selective sigma-2 receptor ligand $\left[K_{\mathrm{i}} 8.2 \mathrm{nM}\right.$ and $12,900 \mathrm{nM}$ for sigma-2 and sigma-1 receptors, respectively (Hou et al., 2006; Zeng et al., 2019)] was unable to detect this residual binding when used as the radioligand. In this way, $\left[{ }^{125} \mathrm{I}\right]$ RHM-4 binding the sigma-2 receptor reflects the beauty of $\left[{ }^{3} \mathrm{H}\right](+)$ pentazocine when studying the sigma-1 receptor. $\left[{ }^{125} \mathrm{I}\right]$ RHM-4 binds the sigma-2 receptor with sufficient dwell time to monitor the interaction readily. Rapid dissociation from the alternative binding sites with low affinity (in this case, sigma-1 receptors) means they do not contribute to any directly observable radioactive signal.

The more recent molecular identification of the sigma-2 receptor (Alon et al., 2017) has allowed the generation of cell lines lacking either sigma-1 receptors (Mavlyutov et al., 2017) or sigma-2 receptors (Riad et al., 2018). Such cell lines may well prove to be useful in dissecting out the cellular roles of the individual receptor types and contribute to the development of more selective ligands for pharmacological and therapeutic use. Furthermore, despite limitations of the models, the availability of knockout mice, such as that for the sigma 1 receptor (Langa et al., 2003), will undoubtedly contribute to a full understanding of the pathophysiological roles of these receptors. Such developments will certainly add to the available tools and methodologies. However, the present importance of identifying and quantifying sigma receptors (particularly sigma-2 receptors), potentially for tumour imaging and as a molecular target in cancer (see Introduction), highlight that robust methodology must be in place. We hope that the work presented here will sound a note of caution with current methodologies and highlight the need for further consideration and development.

\section{AUTHOR'S NOTE}

Figures 1 and 6, and Supplementary Figures 1, 2, 3 and 4 appear in preliminary form in the $\mathrm{PhD}$ thesis by HA (Expression of sigma receptors in human cancer cell lines and effects of novel sigma-2 ligands on their proliferation, University of Wolverhampton, 2018).

\section{DATA AVAILABILITY STATEMENT}

The datasets generated for this study are available on request to the corresponding author.

\section{AUTHOR CONTRIBUTIONS}

$\mathrm{HA}, \mathrm{PB}, \mathrm{GW}$ and SS were involved in performing the experiments described. HA, DF and SS contributed to the modelling. All authors were involved in drafting and preparation of this manuscript.

\section{FUNDING}

We would like to thank Dudley Group of Hospitals NHS Trust, New Cross Hospital NHS Trust and RCSI-Bahrain for the financial support.

\section{SUPPLEMENTARY MATERIAL}

The Supplementary Material for this article can be found online at: https://www.frontiersin.org/articles/10.3389/fphar.2020. 00309/full\#supplementary-material 


\section{REFERENCES}

Abate, C., Elenewski, J., Niso, M., Berardi, F., Colabufo, N. A., Azzariti, A., et al. (2010). Interaction of the sigma(2) receptor ligand PB28 with the human nucleosome: computational and experimental probes of interaction with the H2A/H2B dimer. ChemMedChem 5 (2), 268-273. doi: 10.1002/ cmdc. 200900402

Alon, A., Schmidt, H. R., Wood, M. D., Sahn, J. J., Martin, S. F., and Kruse, A. C. (2017). Identification of the gene that codes for the sigma2 receptor. Proc. Natl. Acad. Sci. U. S. A. 114 (27), 7160-7165. doi: 10.1073/pnas.1705154114

Booth, R. G., and Baldessarini, R. J. (1991). (+)-6,7-benzomorphan sigma ligands stimulate dopamine synthesis in rat corpus striatum tissue. Brain Res. 557 (1-2), 349-352. doi: 10.1016/0006-8993(91)90159-S

Bowen, W. D. (2000). Sigma receptors: recent advances and new clinical potentials. Pharm. Acta Helv. 74 (2-3), 211-218. doi: 10.1016/S0165-7208 (00)80020-3

Brimson, J. M., Brown, C. A., and Safrany, S. T. (2011). Antagonists show GTPsensitive high-affinity binding to the sigma-1 receptor. Br. J. Pharmacol. 164 (2b), 772-780. doi: 10.1111/j.1476-5381.2011.01417.x

Brimson, J. M., Safrany, S. T., Qassam, H., and Tencomnao, T. (2018). Dipentylammonium binds to the sigma-1 receptor and protects against glutamate toxicity, attenuates dopamine toxicity and potentiates neurite outgrowth in various cultured cell lines. Neurotox. Res. 34 (2), 263-272. doi: $10.1007 / \mathrm{s} 12640-018-9883-5$

Chu, U. B., and Ruoho, A. E. (2015). Sigma receptor binding assays. Curr. Protoc. Pharmacol. 71, 134 31-31 34 21. doi: 10.1002/0471141755.ph0134s71

Chu, U. B., Mavlyutov, T. A., Chu, M. L., Yang, H., Schulman, A., Mesangeau, C., et al. (2015). The Sigma-2 Receptor and Progesterone Receptor Membrane Component 1 are different binding sites derived from independent genes. EBioMedicine 2 (11), 1806-1813. doi: 10.1016/ j.ebiom.2015.10.017

Gonzalez-Alvear, G. M., and Werling, L. L. (1995). Sigma receptor regulation of norepinephrine release from rat hippocampal slices. Brain Res. 673 (1), 61-69. doi: 10.1016/0006-8993(94)01394-W

GraphPad (2020). Advice: Avoid Scatchard, Lineweaver-Burke and similar transforms. [Online]. Available: https://www.graphpad.com/guides/prism/8/ curve-fitting/avoidscatchard_lineweaver_burkeandsimilartransforms.htm?q= scatchard [Accessed 23 January 2020].

Hanner, M., Moebius, F. F., Flandorfer, A., Knaus, H. G., Striessnig, J., Kempner, E., et al. (1996). Purification, molecular cloning, and expression of the mammalian sigmal-binding site. Proc. Natl. Acad. Sci. U. S. A. 93 (15), 8072-8077. doi: $10.1073 /$ pnas.93.15.8072

Hou, C., Tu, Z., Mach, R., Kung, H. F., and Kung, M. P. (2006). Characterization of a novel iodinated sigma-2 receptor ligand as a cell proliferation marker. Nucl. Med. Biol. 33 (2), 203-209. doi: 10.1016/ j.nucmedbio.2005.10.001

Kekuda, R., Prasad, P. D., Fei, Y. J., Leibach, F. H., and Ganapathy, V. (1996). Cloning and functional expression of the human type 1 sigma receptor (hSigmaR1). Biochem. Biophys. Res. Commun. 229 (2), 553-558. doi: 10.1006/bbrc.1996.1842

King, M., Pan, Y. X., Mei, J., Chang, A., Xu, J., and Pasternak, G. W. (1997). Enhanced kappa-opioid receptor-mediated analgesia by antisense targeting the sigmal receptor. Eur. J. Pharmacol. 331 (1), R5-R6. doi: 10.1016/S0014-2999 (97)01064-9

Kovacs, K. J., and Larson, A. A. (1995). Discrepancies in characterization of sigma sites in the mouse central nervous system. Eur. J. Pharmacol. 285 (2), 127-134. doi: 10.1016/0014-2999(95)00383-v

Langa, F., Codony, X., Tovar, V., Lavado, A., Gimenez, E., Cozar, P., et al. (2003). Generation and phenotypic analysis of sigma receptor type I (sigma 1) knockout mice. Eur. J. Neurosci. 18 (8), 2188-2196. doi: 10.1046/j.14609568.2003.02950.x

Lazareno, S., and Birdsall, N. J. (2000). Effects of contamination on radioligand binding parameters. Trends Pharmacol. Sci. 21 (2), 57-60. doi: 10.1016/S01656147(99)01412-1

Lever, J. R., Gustafson, J. L., Xu, R., Allmon, R. L., and Lever, S. Z. (2006). Sigma1 and sigma2 receptor binding affinity and selectivity of SA4503 and fluoroethyl SA4503. Synapse 59 (6), 350-358. doi: 10.1002/syn.20253
Lever, J. R., Litton, T. P., and Fergason-Cantrell, E. A. (2015). Characterization of pulmonary sigma receptors by radioligand binding. Eur. J. Pharmacol. 762, 118-126. doi: 10.1016/j.ejphar.2015.05.026

Martin, W. R., Eades, C. G., Thompson, J. A., Huppler, R. E., and Gilbert, P. E. (1976). The effects of morphine- and nalorphine- like drugs in the nondependent and morphine-dependent chronic spinal dog. J. Pharmacol. Exp. Ther. 197 (3), 517-532.

Maurice, T., and Lockhart, B. P. (1997). Neuroprotective and anti-amnesic potentials of sigma (sigma) receptor ligands. Prog. Neuropsychopharmacol. Biol. Psychiatry 21 (1), 69-102. doi: 10.1016/S0278-5846(96)00160-1

Mavlyutov, T. A., Yang, H., Epstein, M. L., Ruoho, A. E., Yang, J., and Guo, L. W. (2017). APEX2-enhanced electron microscopy distinguishes sigma-1 receptor localization in the nucleoplasmic reticulum. Oncotarget 8 (31), 51317-51330. doi: 10.18632/oncotarget.17906

Mei, J., and Pasternak, G. W. (2001). Molecular cloning and pharmacological characterization of the rat sigmal receptor. Biochem. Pharmacol. 62 (3), 349355. doi: 10.1016/S0006-2952(01)00666-9

Monnet, F. P., de Costa, B. R., and Bowen, W. D. (1996). Differentiation of sigma ligand-activated receptor subtypes that modulate NMDA-evoked [3H]noradrenaline release in rat hippocampal slices. Br. J. Pharmacol. 119 (1), 65-72. doi: 10.1111/j.1476-5381.1996.tb15678.x

Patrick, S. L., Walker, J. M., Perkel, J. M., Lockwood, M., and Patrick, R. L. (1993). Increases in rat striatal extracellular dopamine and vacuous chewing produced by two sigma receptor ligands. Eur. J. Pharmacol. 231 (2), 243-249. doi: 10.1016/0014-2999(93)90456-R

Paul, I. A., Basile, A. S., Rojas, E., Youdim, M. B. H., Decosta, B., Skolnick, P., et al. (1993). Sigma-Receptors Modulate Nicotinic Receptor Function in Adrenal Chromaffin Cells. FASEB J. 7 (12), 1171-1178. doi: 10.1096/ fasebj.7.12.8375616

Radif, Y., Ndiaye, H., Kalantzi, V., Jacobs, R., Hall, A., Minogue, S., et al. (2018). The endogenous subcellular localisations of the long chain fatty acid-activating enzymes ACSL3 and ACSL4 in sarcoma and breast cancer cells. Mol. Cell. Biochem. 448 (1-2), 275-286. doi: 10.1007/s11010-018-3332-x

Riad, A., Zeng, C., Weng, C. C., Winters, H., Xu, K., Makvandi, M., et al. (2018). Sigma-2 receptor/TMEM97 and PGRMC-1 increase the rate of internalization of LDL by LDL receptor through the formation of a ternary complex. Sci. Rep. 8 (1), 16845. doi: 10.1038/s41598-018-35430-3

Rodbard, D., Munson, P. J., and Thakur, A. K. (1980). Quantitative characterization of hormone receptors. Cancer 46 (12), 2907-2918. doi: 10.1002/1097-0142(19801215)46:12+<2907::Aid-Cncr28204614 33>3.0.Co;2-6

Schetz, J. A., Perez, E., Liu, R., Chen, S. W., Lee, I., and Simpkins, J. W. (2007). A prototypical Sigma-1 receptor antagonist protects against brain ischemia. Brain Res. 1181, 1-9. doi: 10.1016/j.brainres.2007.08.068

Schmidt, H. R., Zheng, S., Gurpinar, E., Koehl, A., Manglik, A., and Kruse, A. C. (2016). Crystal structure of the human sigmal receptor. Nature 532 (7600), 527-530. doi: 10.1038/nature17391

Shiba, K., Ogawa, K., and Mori, H. (2005). In vitro characterization of radioiodinated (+)-2-[4-(4-iodophenyl) piperidino]cyclohexanol [(+)-pIV] as a sigma-1 receptor ligand. Bioorg. Med. Chem. 13 (4), 1095-1099. doi: 10.1016/ j.bmc.2004.11.029

Spruce, B. A., Campbell, L. A., McTavish, N., Cooper, M. A., Appleyard, M. V., O'Neill, M., et al. (2004). Small molecule antagonists of the sigma-1 receptor cause selective release of the death program in tumor and self-reliant cells and inhibit tumor growth in vitro and in vivo. Cancer Res. 64 (14), 4875-4886. doi: 10.1158/0008-5472.CAN-03-3180

Stracina, T., and Novakova, M. (2018). Cardiac Sigma Receptors - An Update. Physiol. Res. 67, S561-S576. doi: 10.33549/physiolres.934052

Sunnam, S. K., Rack, E., Schepmann, D., and Wunsch, B. (2011). Synthesis of 7,9diazabicyclo[4.2.2] decanes as conformationally restricted kappa receptor agonists: Fine tuning of the dihedral angle of the ethylenediamine pharmacophore. Eur. J. Med. Chem. 46 (6), 1972-1982. doi: 10.1016/ j.ejmech.2011.01.064

van Waarde, A., Rybczynska, A. A., Ramakrishnan, N. K., Ishiwata, K., Elsinga, P. H., and Dierckx, R. A. (2015). Potential applications for sigma receptor ligands in cancer diagnosis and therapy. Biochim. Biophys. Acta 1848 (10 Pt B), 2703-2714. doi: 10.1016/j.bbamem.2014.08.022 
Vilner, B. J., John, C. S., and Bowen, W. D. (1995). Sigma-1 and sigma-2 receptors are expressed in a wide variety of human and rodent tumor cell lines. Cancer Res. 55 (2), 408-413.

Walker, J. M., Bowen, W. D., Walker, F. O., Matsumoto, R. R., De Costa, B., and Rice, K. C. (1990). Sigma receptors: biology and function. Pharmacol. Rev. 42 (4), 355-402.

Xu, J., Tu, Z., Jones, L. A., Vangveravong, S., Wheeler, K. T., and Mach, R. H. (2005). [3H]N-[4-(3,4-dihydro-6,7-dimethoxyisoquinolin-2(1H)-yl)butyl]-2methoxy-5-methyl benzamide: a novel sigma-2 receptor probe. Eur. J. Pharmacol. 525 (1-3), 8-17. doi: 10.1016/j.ejphar.2005.09.063

Xu, R., Lord, S. A., Peterson, R. M., Fergason-Cantrell, E. A., Lever, J. R., and Lever, S. Z. (2015). Ether modifications to 1-[2-(3,4-dimethoxyphenyl)ethyl]-4-(3phenylpropyl)piperazine (SA4503): effects on binding affinity and selectivity for sigma receptors and monoamine transporters. Bioorg. Med. Chem. 23 (1), 222-230. doi: 10.1016/j.bmc.2014.11.007

Zampieri, D., Mamolo, M. G., Laurini, E., Florio, C., Zanette, C., Fermeglia, M., et al. (2009). Synthesis, biological evaluation, and three-dimensional in silico pharmacophore model for sigma(1) receptor ligands based on a series of substituted benzo[d]oxazol-2(3H)-one derivatives. J. Med. Chem. 52 (17), 5380-5393. doi: 10.1021/jm900366z
Zeng, C., McDonald, E. S., and Mach, R. H. (2017). Molecular probes for imaging the sigma-2 receptor: in vitro and in vivo imaging studies. Handb. Exp. Pharmacol. 244, 309-330. doi: 10.1007/164_2016_96

Zeng, C., Weng, C. C., Schneider, M. E.Jr., Puentes, L., Riad, A., Xu, K., et al. (2019). TMEM97 and PGRMC1 do not mediate sigma-2 ligand-induced cell death. Cell Death Discov. 5, 58. doi: 10.1038/s41420-019-0141-2

Conflict of Interest: Author DF is employed by Eli Lilly.

The remaining authors declare that the research was conducted in the absence of any commercial or financial relationships that could be construed as a potential conflict of interest.

Copyright (C) 2020 Abbas, Borde, Willars, Ferry and Safrany. This is an open-access article distributed under the terms of the Creative Commons Attribution License (CC BY). The use, distribution or reproduction in other forums is permitted, provided the original author(s) and the copyright owner(s) are credited and that the original publication in this journal is cited, in accordance with accepted academic practice. No use, distribution or reproduction is permitted which does not comply with these terms. 